\title{
The Effect of Induced Standing Reflex, Cervical Stimulation and Insemination on Intraluminal Pressure Variations in the Isthmus of the Oviduct in Unrestrained Gilts
}

\author{
By $A$. Pettersson
}

Department of Obstetrics and Gynaecology, Faculty of Veterinary Medicine, Swedish University of Agricultural Sciences, Uppsala, Sweden.

\begin{abstract}
Pettersson, A.: The effect of induced standing reflex, cervical stimulation and insemination on intraluminal pressure variations in the isthmus of the oviduct in unrestrained gilts. Acta vet. scand. 1993, 34, 117-124. - Four gilts were each equipped with 2 ultra-miniature pressure sensors, placed at 2 different points along the same isthmus of the oviduct, on the morning of the first day of standing oestrus (Day 1). Intraluminal pressure recordings were started the same afternoon. After an initial recording period, intraluminal pressure was recorded while the gilts showed standing oestrus and during cervical stimulation followed by insemination with either $100 \mathrm{ml}$ saline or $100 \mathrm{ml}$ boar semen. Monitoring of the pressure variations in the isthmus was continued for up to 6.5 $\mathrm{h}$ after the last insemination. Blood samples for monitoring oestradiol-17B, progesterone and 15-ketodihydroprostaglandin $F_{2 \alpha}$ were collected before and after each manipulation of the gilt and every $30 \mathrm{~min}$ during the rest of the test period. None of the above manipulations had any consistent effect on the intraluminal pressure in the porcine isthmus, although, a clear 15 -ketodihydroprostaglandin $F_{2 \alpha}$ peak could be seen after insemination with boar semen.
\end{abstract}

oviductal isthmus; porcine; prostaglandin $F_{2 a^{*}}$

\section{Introduction}

Under natural conditions gilts showing signs of standing oestrus are mated and a large volume of semen is propelled directly into the uterus. Although spermatozoa can be found in the oviducts shortly after mating (First et al. 1968), they are mainly limited to the uterotubal junction (UTJ) and the caudal portion of the oviductal isthmus (Hunter \& Léglise 1971, Hunter 1975, Viring et al. 1980, Fléchon \& Hunter 1981). Evidence has been presented suggesting that the porcine isthmus and UTJ play an active role in limiting the ascent of spermatozoa to the ampullary-isthmic junc- tion (AIJ), where fertilization occurs (Hunter \& Léglise 1971). The oedematous condition of the luminal folds and the processes of the UTJ (Andersen 1928, Hunter 1981) together with the high intraluminal pressure measured in the isthmus of the oviduct during standing oestrus (Pettersson 1991) may be important factors in the regulation of sperm admission to the oviduct and the establishment of a sperm reservoir. It is, however, possible that various stimuli involved in the process of mating and the gametes themselves may affect the conditions in the oviduct. In this study, the effects of induced standing reflex, cervical stim- 
ulation and insemination, with either $100 \mathrm{ml}$ saline, or $100 \mathrm{ml}$ fresh semen from a fertile boar on the intraluminal pressure in the oviductal isthmus in unrestrained gilts were examined.

\section{Materials and methods \\ Animals}

Four mature cycling Swedish Yorkshire gilts were used as test animals. They were housed indoors in a conventional stable and checked for standing oestrus twice daily, in the presence of a mature boar, by experienced personnel. The gilts had shown at least 1 oestrus prior to use in the experiment. Each gilt was used only once. Special care was taken to accustom the gilts to human handling, in order to minimize stress during the test period.

\section{Surgery}

The gilts were equipped with chronic jugular vein catheters (Rodriguez \& Kunavongkrit 1983) 1 week before expected oestrus. Blood samples could thereby be collected without disturbing the animal. Early, on the morning of the first day of standing oestrus (Day 1 of the oestrous cycle), 2 ultra-miniature pressure sensors (PR-249, Millar Instr., USA), each located at the distal end of a $140 \mathrm{~cm}$ long dacron catheter with an electrical connector at its proximal end, were passed from the lumbar back subcutaneously, and placed at 2 different points along the same isthmus. The electrical connectors were placed in a canvas bag sutured to the animal's back. A $5 \%$ aqueous solution of thiopentone sodium (Pentothal Sodium, Abbott) was used for inducing general anaesthesia while inhalation of halothane (Halothan, Hoechst, Germany) was used for maintaining anaesthesia. This method has previously been described in detail (Henriksson et al. 1987). The gilts were then returned to the stable.

\section{Experimental Design}

The gilts were allowed to regain consciousness and the experiment was started late, on the afternoon of the same day. During an initial period of $30 \mathrm{~min}$, intraluminal pressure recordings were made, prior to exposing the gilts to a boar. Gilt no. 1 was moved to a farrowing crate positioned in front of the boar's pen, while the remaining 3 gilts stayed in their own pens and the boar was instead moved into an adjacent pen with rather large holes in the wall, through which the boar was able to nuzzle the gilts but not mount them. The standing reflex was induced manually in the presence of the boar. Intraluminal pressure was monitored continuously. After 5 to 10 min, a sterile rubber insemination catheter was introduced into the cervix while the gilt exhibited the standing reflex. The cervix was stimulated for 5 to 10 minutes. This procedure was repeated in gilt no. 1 after a $30 \mathrm{~min}$ period of intraluminal pressure recordings without the presence of the boar. After the second period of cervix stimulation, she was directly inseminated with $100 \mathrm{ml}$ body temperature saline solution. Gilt no. 2 was inseminated with $100 \mathrm{ml}$ saline after the first period of cervix stimulation. The boar was then removed and after $60 \mathrm{~min}$, during which time intraluminal pressure was continuously recorded, the boar was returned and the process of inducing standing reflex and cervical stimulation was repeated. The gilt was then inseminated with $100 \mathrm{ml}$ filtered fresh semen, manually collected from a fertile boar. The remaining 2 gilts were only induced to show the standing reflex once and each cervix stimulated once after which they were directly inseminated with $100 \mathrm{ml}$ fresh filtered boar semen from a fertile boar. The insemination doses used contained between 21 and $36 \times 10^{9}$ spermatozoa. The oestrogen content in the inseminates varied. The oestradiol-17ß levels ranged from 
$224 \mathrm{pmol} / \mathrm{l}$ to $584 \mathrm{pmol} / \mathrm{l}$ while oestrone sulphate levels ranged from $0.3 \mathrm{nmol} / 1$ to 5.6 nmol/l. Intraluminal pressure recordings were continued for up to $6.5 \mathrm{~h}$ after the last insemination. The pressure sensors were later removed by laparotomy. The proper positions of the pressure sensors were confirmed and the ovary and oviduct carefully inspected. After slaughter, which occurred at a later date, sections from both oviducts of each gilt were removed. Histological preparations of the oviducts were later compared under a light microscope.

\section{Blood samples and analytical methods}

Blood samples were collected into heparinized Vacutainer ${ }^{\circledR}$ tubes (Becton and Dickinson, Rutherford, USA) every $30 \mathrm{~min}$ and also before and after each manipulation of the gilt. The blood samples were immediately centrifuged and the plasma withdrawn and stored at $-20^{\circ} \mathrm{C}$ until hormonal analysis could be made. The blood samples were later analysed for levels of the main prostaglandin $\mathrm{F}_{2 \alpha}\left(\mathrm{PGF}_{2 \alpha}\right)$ metabolite, 15-ketodihydroprostaglandin $\mathrm{F}_{2 \alpha}$ (Granström \& Kindahl 1982), oestradiol-17ß (Boilert et al. 1973), and progesterone (Bosu et. al. 1976), using radioimmunoassays. Oestrone sulphate was determined, using a modified version of the radioimmunoassay described by Kindahl et al. (1982). Oestradiol$17 ß$ and oestrone sulphate levels were also determined in the semen, used in the experiment utilizing the same techniques. The methods used for progesterone, oestradiol-17ß and 15ketodihydro-PGF ${ }_{2 \alpha}$ have earlier been validated for the porcine species (Kunavongkrit et al. 1983).

\section{Calculations}

Oviductal intraluminal pressure can be described as being composed of phasic pressure fluctuations superimposed upon a base pres-

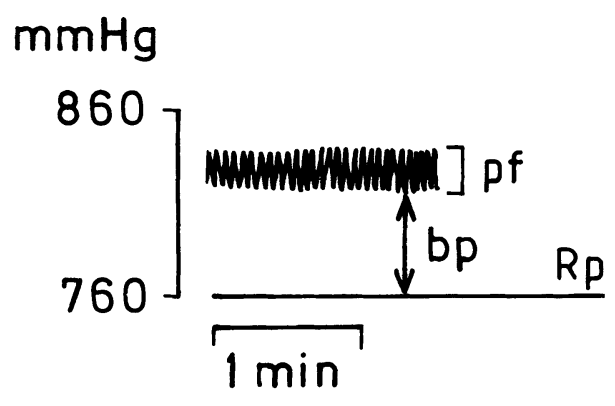

Fig. 1. Example of the phasic pressure fluctuations in the isthmus. Rp: atmospheric pressure, bp: base pressure, pf: phasic pressure fluctuations.

sure (Fig. 1). The phasic pressure fluctuations can be arranged in a wavy, irregular or regular pattern with stable resting pressures and amplitudes. Outbursts of increased intraluminal pressure were defined as marked increases in intraluminal pressure, where the lowest resting pressure of the phasic pressure fluctuations at the peak of the outburst was greater than the total pressure of the registration period. Prior to insertion, the pressure sensors were calibrated to the atmospheric pressure of the operation day. This pressure was used as a reference during the entire test period. The base pressure was defined as the lowest resting pressure of the phasic pressure variations during 5 or 10 min periods. The total pressures for these periods were derived by adding the sum of the mean amplitudes of the phasic pressure fluctuations during 2 nonconsecutive min to the base pressure. The frequency of the phasic pressure fluctuations was also determined. Calculations were based on the recordings obtained from the distal pressure sensor. The proximal pressure sensor was used for determining the propagation direction of outbursts of increased intraluminal pressure. 


\section{Results}

As seen in Table 1, none of the stimuli to which the gilts were exposed resulted in any consistent alteration of the intraluminal pressure parameters recorded. The pattern in which the phasic pressure fluctuations were arranged was not affected by any of the treatments. One outburst of increased intraluminal pressure was seen in gilt no. 1 about $45 \mathrm{~min}$ after insemination with saline. This outburst occurred simultanously at both points of registration. The 2 gilts (gilts nos. 3 and 4) inseminated with boar semen had a 15-ketodihydro-PGF ${ }_{2 \alpha}$ peak which started approximately 220 and 255 min respectively after insemination. The levels of 15-ketodihydro$\mathrm{PGF}_{2 \alpha}$ in gilt no. 1 , who had been inseminated with saline only, did not increase after insemination. Gilt no. 2, having been inseminated with both saline and semen, showed a tendency for a peak towards the end of the registration about $250 \mathrm{~min}$ after insemination with boar semen (Table 2). These prostaglandin peaks were not followed by any consistent change in the intraluminal pressure parameters. Oestradiol-17ß and oestrone sulphate levels in the peripheral circulation remained uneffected by the insemination procedures.

No adhesions were seen involving the oviduct when removing the pressure sensors on the following day. The positions of the pressure sensors had not changed during the test period. All gilts had ovulated. The histological examination did not reveal any damage to the oviduct.

\section{Discussion}

Judging from the results obtained in this study, it does not seem as though the processes of induced standing reflex or cervical stimulation have any consistent effect on the intraluminal pressure in the isthmus of the oviduct in unrestrained gilts. These findings are in line with the results obtained by Bower (1974), who found that external stimuli did not enhance uterine contractions in conscious pigs.

Mechanical stimulation of the cow's reproductive organs has been shown to stimulate the release of oxytocin (Schams et al. 1982). Although exogenous administration of oxytocin in anaesthetized gilts has been shown to increase oviductal activity during oestrus (Zerobin \& Spörri 1972), no consistent response to the mechanical stimulation of the cervix was seen in the present study. One explanation for this might be that the pig does not always respond to mechanical stimulation of the reproductive organs by releasing oxytocin, as shown by Claus (1990). Further, the pharmacological and physiological effects of oxytocin on the oviduct may differ.

Uterine contractility is high during oestrus (Zerobin \& Spörri 1972, Bower 1974, Claus et al. 1989). Further, myometrial activity can be enhanced by insemination both in vivo in anaesthetized sows (Zerobin \& Spörri 1972) and in conscious pigs (Bower 1974). Uterine contractions in association with mating are thought to be actively involved in the transport of spermatozoa through the uterus to the UTJ (Hunter 1973). In the present study, however, no consistent effect of the insemination processes on the intraluminal pressure in the oviductal isthmus could be seen.

Claus et al. (1987) have suggested that the high oestrogen concentration in boar semen stimulates the uterus to synthesize, in particular, $\mathrm{PGF}_{2 \alpha}$ which in turn enhances uterus contractions. Claus et al. (1990) found that after mating, 15-ketodihydro-PGF ${ }_{2 \alpha}$ concentrations showed a biphasic pattern in peripheral plasma, which was also reflected by the oestradiol profile. Since half of the seminal oestrogens are bound to the spermatozoa (Claus et al. 1985), the biphasic pattern was explained 
Table 1. The base pressure (BP), total pressure (TP) in $\mathrm{mmHg}$, and frequency (F) of the phasic pressure fluctuations before, during and after induced standing reflex (S), cervical stimulation (C) and insemination with 100 $\mathrm{ml}$ saline (I) or $100 \mathrm{ml}$ boar semen (IB). SD is the standard deviation of the amplitudes, expressed in $\mathrm{mmHg}$, of the phasic pressure fluctuations included in each total pressure.

\begin{tabular}{|c|c|c|c|c|c|c|c|c|c|c|c|}
\hline \multirow[b]{2}{*}{ Min } & \multicolumn{5}{|c|}{ Gilt 1} & \multicolumn{6}{|c|}{ Gilt 2} \\
\hline & Stim.* & B & TP & (SD) & $\mathrm{F}$ & Min & Stim. & B & TP & (SD) & F \\
\hline $0-10$ & & 790 & 870 & (18) & 37 & $0-10$ & & 765 & 833 & (21) & 38 \\
\hline $10-20$ & & 780 & 883 & (18) & 36 & $20-30$ & & 775 & 835 & (23) & 41 \\
\hline $55-60$ & $S$ & 800 & 887 & (10) & 37 & $35-40$ & $S$ & 775 & 842 & (8) & 43 \\
\hline $60-70$ & SC & 790 & 876 & (15) & 37 & $45-50$ & $\mathrm{SC}$ & 785 & 862 & (20) & 45 \\
\hline $90-100$ & & 780 & 845 & (10) & 36 & $55-60$ & SCI & 765 & 849 & (24) & 44 \\
\hline $120-125$ & $\mathrm{SC}$ & 780 & 862 & (30) & 38 & $80-90$ & & 765 & 819 & (21) & 40 \\
\hline $125-130$ & SCI & 780 & 853 & (21) & 38 & $110-120$ & & 765 & 841 & (16) & 39 \\
\hline $130-140$ & & 770 & 849 & (13) & 34 & $120-125$ & S & 765 & 826 & (7) & 44 \\
\hline $160-170$ & & 770 & 834 & (16) & 34 & $130-135$ & SC & 765 & 823 & (19) & 43 \\
\hline $190-200$ & & 780 & 876 & (18) & 34 & $140-145$ & SCIB & 765 & 815 & (20) & 39 \\
\hline $220-230$ & & 770 & 841 & (19) & 33 & $150-160$ & & 775 & 815 & (19) & 37 \\
\hline $250-260$ & & 770 & 840 & (40) & 37 & $170-180$ & & 765 & 814 & (18) & 41 \\
\hline $280-290$ & & 780 & 873 & (40) & 35 & $200-210$ & & 765 & 822 & (16) & 40 \\
\hline $310-320$ & & 780 & 862 & (16) & 35 & $230-240$ & & 765 & 817 & (25) & 41 \\
\hline $340-350$ & & 790 & 892 & (28) & 34 & $260-270$ & & 765 & 827 & (22) & 40 \\
\hline \multirow[t]{5}{*}{$370-380$} & & 790 & 892 & (26) & 33 & $290-300$ & & 775 & 814 & (18) & 40 \\
\hline & & & & & & $320-330$ & & 765 & 809 & (15) & 42 \\
\hline & & & & & & $350-360$ & & 765 & 835 & (21) & 43 \\
\hline & & & & & & $380-390$ & & 765 & 830 & (18) & 41 \\
\hline & & & & & & $410-420$ & & 775 & 848 & (16) & 44 \\
\hline
\end{tabular}

Gilt 3

\begin{tabular}{|c|c|c|c|c|c|c|c|c|c|c|c|}
\hline Min & Stim. & B & TP & (SD) & $\mathrm{F}$ & Min & Stim. & B & $\mathrm{TP}$ & (SD) & $\mathrm{F}$ \\
\hline $0-10$ & & 798 & 886 & (18) & 41 & $0-10$ & & 806 & 921 & (22) & 44 \\
\hline $25-30$ & & 788 & 871 & (18) & 34 & $20-30$ & & 816 & 942 & (22) & 45 \\
\hline $35-40$ & $\mathrm{~S}$ & 788 & 848 & (25) & 40 & $40-45$ & $S$ & 806 & 903 & (32) & 49 \\
\hline $45-50$ & SC & 788 & 868 & (20) & 40 & $50-55$ & SC & 806 & 929 & (24) & 45 \\
\hline $55-60$ & SCIB & 788 & 846 & (27) & 38 & $55-60$ & SCIB & 816 & 932 & (26) & 44 \\
\hline $60-65$ & $\mathrm{C}$ & 778 & 848 & (21) & 39 & $65-70$ & & 826 & 937 & (17) & 45 \\
\hline $90-100$ & & 778 & 840 & (25) & 35 & $95-105$ & & 806 & 939 & (28) & 43 \\
\hline $120-130$ & & 768 & 832 & (18) & 36 & $125-135$ & & 806 & 938 & (17) & 38 \\
\hline $150-160$ & & 778 & 839 & (20) & 33 & $155-165$ & & 806 & 923 & (21) & 38 \\
\hline $180-190$ & & 778 & 856 & (17) & 35 & $185-195$ & & 806 & 924 & (10) & 42 \\
\hline $210-220$ & & 778 & 842 & (22) & 36 & $215-225$ & & 806 & 932 & (13) & 43 \\
\hline $240-250$ & & 778 & 847 & (26) & 36 & $245-255$ & & 796 & 903 & (13) & 43 \\
\hline $270-280$ & & 776 & 881 & (30) & 36 & $275-285$ & & 786 & 910 & (17) & 40 \\
\hline $300-310$ & & 776 & 861 & (21) & 40 & $305-315$ & & 786 & 894 & (13) & 41 \\
\hline $330-340$ & & 776 & 882 & (24) & 38 & $335-345$ & & 786 & 896 & (20) & 42 \\
\hline $360-370$ & & 788 & 848 & (13) & 38 & $365-375$ & & 806 & 912 & (20) & 43 \\
\hline $390-400$ & & 788 & 851 & (14) & 37 & $395-405$ & & 796 & 914 & (12) & 43 \\
\hline $420-430$ & & 798 & 894 & (24) & 36 & $425-435$ & & 786 & 897 & (17) & 43 \\
\hline
\end{tabular}

* Stim. $=$ method of stimulation. 
Table 2. Peripheral plasma levels of oestradiol-17B $\left(\mathrm{E}_{2}\right)$ and 15-ketodihydro-PGF $\mathrm{F}_{2 \alpha}(\mathrm{PG})$ before and after inducing standing reflex (S), cervical stimulation (C) and insemination with saline (I) or boar semen (IB).

\begin{tabular}{|c|c|c|c|c|c|c|c|}
\hline \multirow[b]{2}{*}{ Min } & \multicolumn{3}{|c|}{ Gilt 1} & \multirow[b]{2}{*}{ Min } & \multirow[b]{2}{*}{ Stim. } & \multicolumn{2}{|c|}{ Gilt 2} \\
\hline & Stim.* & $\begin{array}{l}\mathrm{E}_{2} \\
(\mathrm{pmol} / \mathrm{l})\end{array}$ & $\begin{array}{l}\text { PG } \\
(\mathrm{pmol} / \mathrm{l})\end{array}$ & & & $\begin{array}{l}\mathrm{E}_{2} \\
(\mathrm{pmol} / \mathrm{l})\end{array}$ & $\begin{array}{l}\text { PG } \\
(\mathrm{pmol} / \mathrm{l})\end{array}$ \\
\hline 0 & & 80 & 275 & 0 & & 56 & 451 \\
\hline 20 & & 87 & 243 & 30 & & 54 & 366 \\
\hline 60 & S & 69 & 236 & 40 & S & 52 & 566 \\
\hline 70 & SC & 49 & 233 & 50 & SC & 60 & 651 \\
\hline 100 & & 58 & 199 & 60 & SCI & 46 & 471 \\
\hline 115 & & 43 & 317 & 90 & & 32 & 489 \\
\hline 125 & SC & 33 & 221 & 120 & & 34 & 405 \\
\hline 130 & SCI & 50 & 276 & 125 & $\mathrm{~S}$ & 46 & 464 \\
\hline 140 & & - & - & 135 & SC & 34 & 452 \\
\hline 170 & & 66 & 247 & 145 & SCIB & 32 & 420 \\
\hline 200 & & 63 & 205 & 160 & & - & - \\
\hline 230 & & 60 & 161 & 180 & & 34 & 313 \\
\hline 260 & & 59 & 256 & 210 & & 36 & 303 \\
\hline 290 & & 71 & 212 & 240 & & 41 & 364 \\
\hline 320 & & 57 & 207 & 270 & & 25 & 361 \\
\hline 350 & & 55 & 222 & 300 & & 35 & 328 \\
\hline \multirow[t]{4}{*}{380} & & 64 & 177 & 330 & & 31 & 308 \\
\hline & & & & 360 & & 24 & 261 \\
\hline & & & & 390 & & 26 & 554 \\
\hline & & & & 420 & & 20 & 667 \\
\hline
\end{tabular}

Gilt 3

\begin{tabular}{|c|c|c|c|c|c|c|c|}
\hline & & & & & & & \\
\hline Min & Stim. & $\begin{array}{l}\mathrm{E}_{2} \\
(\mathrm{pmol} / \mathrm{l})\end{array}$ & $\begin{array}{l}\text { PG } \\
(\mathrm{pmol} / \mathrm{l})\end{array}$ & Min & Stim. & $\begin{array}{l}\mathrm{E}_{2} \\
(\mathrm{pmol} / \mathrm{l})\end{array}$ & $\begin{array}{l}\mathrm{PG} \\
(\mathrm{pmol} / \mathrm{l})\end{array}$ \\
\hline 0 & & 66 & 575 & 0 & & 27 & 1000 \\
\hline 30 & & 40 & 430 & 30 & & 28 & 918 \\
\hline 40 & S & 68 & 405 & 45 & $S$ & 21 & 945 \\
\hline 50 & SC & 64 & 405 & 55 & SC & 26 & 922 \\
\hline 60 & SCIB & 46 & 405 & 60 & SCIB & 17 & 536 \\
\hline 65 & $\mathrm{C}$ & 61 & 385 & 65 & & 22 & 667 \\
\hline 100 & & 57 & 313 & 70 & & 24 & 753 \\
\hline 130 & & 62 & 400 & 105 & & 28 & 527 \\
\hline 160 & & 46 & 420 & 135 & & 25 & 536 \\
\hline 190 & & 50 & 573 & 165 & & 23 & 590 \\
\hline 220 & & 43 & 496 & 195 & & 26 & 641 \\
\hline 250 & & 42 & 522 & 225 & & 20 & 641 \\
\hline 280 & & 58 & 1156 & 255 & & 20 & 521 \\
\hline 310 & & 43 & 1352 & 285 & & 38 & 356 \\
\hline 340 & & 48 & 3376 & 315 & & 43 & 616 \\
\hline 370 & & 41 & 2122 & 345 & & 22 & 1488 \\
\hline 400 & & 39 & 1059 & 375 & & 20 & 1032 \\
\hline 430 & & 59 & 988 & 405 & & 20 & 835 \\
\hline & & & & 435 & & 26 & 435 \\
\hline
\end{tabular}

* Stim. $=$ method of stimulation. 
as a result of a delayed release of the spermbound oestrogens. The insemination procedures used in the present study did not lead to any peaks in the levels of oestradiol-17ß in peripheral circulation. The increase in the prostaglandin metabolite seen 220 or 255 min after insemination might be a result of the leukocyte invasion into the uterus, which is normally seen after mating (Lovell \& Getty 1968). It is interesting to note that although exogenous administration of $\mathrm{PGF}_{2 \alpha}$ is known to stimulate contractility in the porcine oviduct, both in vitro and in vivo (Rodriguez-Martinez \& Einarsson 1985), no increased activity was seen in the isthmus corresponding to the 15ketodihydro- $\mathrm{PGF}_{2 \alpha}$ peaks. One possible explanation for the lack of effect might be that some or all of the prostaglandins resorbed from the uterus might not reach the oviduct, but instead are metabolized and thereby inactivated in the lung. It is also possible that a corresponding increase in $\mathrm{PGE}_{2}$, which has a relaxing effect on the isthmus during oestrus (Rodriguez-Martinez \& Einarsson 1985), may occur, which would counteract the effect of $\mathrm{PGF}_{2 \alpha}$ on the oviduct.

\section{Conclusions}

No consistent effect on the intraluminal pressure in the isthmus of the oviduct was seen following induced standing reflex, stimulation of the cervix and insemination of saline or boar semen in gilts.

\section{Acknowledgements}

This work has been supported by the Swedish Council for Forestry and Agricultural Research. Special thanks to Prof. Stig Einarsson and Prof. Hans Kindahl for their advice and to Marie Sundberg and Birgitta Berner for secretarial help and to the Department of Clinical Chemistry for performing the steroid analysis.

\section{Rerences}

Andersen DH: Comparative anatomy of the tubouterine junction. Histology and physiology in the sow. Amer. J. Anat. 1928, 42, 255-305.

Boilert B, Edqvist L-E, Johansson EDB, Lindberg P, Martinsson $K$ : The influence of conjugated estrogens in radioimmunoassays using different antibodies against estradiol-17B. Steroids 1973, 22, 891-894.

Bosu WTK, Edqvist L-E, Lindberg P, Martinsson K, Johansson EDB: The effect of various dosages of lynesterol on plasma levels of oestrogens and progesterone during the menstrual cycle in the rhesus monkey. Contraception 1976, 13, 677-684.

Bower RE: Factors affecting myometrial activity in the pig. Ph.D. thesis, University of Minnesota 1974.

Claus R: Physiological role of seminal components in the reproductive tract of the female pig. J. Reprod. Fertil. Suppl. 1990, 40, 117-131.

Claus $R$, Ellendorff $F$, Hoang-Vu C: Spontaneous electromyographic activity throughout the cycle in the sow and its change by intrauterine oestrogen infusion during oestrus. J. Reprod. Fertil. 1989, 87, 543-551.

Claus R, Hoang-Vu C, Ellendorff F, Meyer HD, Schopper D, Weiler U: Seminal oestrogens in the boar: origin and functions in the sow. J. Steroid Biochem. 1987, 27, 331-335.

Claus R, Meyer H-D, Giménez T, Hoang-Vu C, Münster E: Effect of seminal oestrogens of the boar on prostaglandin $F_{2 \alpha}$ release from the uterus of the sow. Anim. Reprod. Sci. 1990, 23, 145-156.

Claus R, Schopper D, Wagner HG, Weiler U: Contribution of individual compartments of the genital tract to oestrogen and testosterone concentrations in ejaculates of the boar. Acta endocr.(Kbh.) 1985, 109, 281-288.

First NL, Short RE, Peters JB, Stratman FW: Transport and loss of boar spermatozoa in the reproductive tract of the sow. J. Anim. Sci. 1968, 27, 1037-1040.

Fléchon J-E, Hunter RHF: Distribution of spermatozoa in the utero-tubal junction and isthmus of pigs and their relationship with the luminal epithelium after mating: a scanning electron microscope study. Tissue Cell 1981, 13, 127-139.

Granström E, Kindahl H: Radioimmunoassay of the major plasma metabolite of $\mathrm{PGF}_{2 \alpha}, 15$-keto13,14-dihydro-PGF ${ }_{2 \alpha}$. Meth. Enzymol. 1982, 86, 302-339. 
Henriksson A, Gustavsson A, Einarsson S: A new method for continuous recording of oviductal pressure variations in unrestrained gilts. Acta physiol. scand. 1987, 131, 303-307.

Hunter RHF: Transport, migration and survival of spermatozoa in the female genital tract: Species with intrauterine deposition of semen. In: Hafez ESE, Thibault C (eds): Sperm Transport, Survival and Fertilization Ability, Paris Inserm 1973, pp 309-342.

Hunter RHF: Physiological aspects of sperm transport in the domestic pig, sus scofa. II. Regulation, survival and fate of cells. Br. vet. J. 1975, 131, 681-690.

Hunter RHF: Sperm transport and reservoirs in the pig in relation to the time of ovulation. J. Reprod. Fert. 1981, 63, 109-117.

Hunter RHF, Léglise PC: Polyspermic fertilization following tubal surgery in pigs with particular reference to the role of the isthmus. J. Reprod. Fert. 1971, 24, 233-246.

Kindahl H, Knudsen O, Madej A, Edqvist L-E: Progesterone, prostaglandin $\mathrm{F}_{-2 \alpha}$, PMSG and oestrone sulphate during early pregnancy in the mare. J. Reprod. Fert. Suppl. 1982, 32, 353-359.

Kunavongkrit $A$, Kindahl $H$, Madej $A$ : Clinical and endocrinological studies in primiparous zeroweaned sows: 2. Hormonal patterns of normal cycling sows after zero-weaning. Zbl. Vet. Med. A. $1983,30,616-624$.

Lovell J, Getty R: Fate of semen in the uterus of the sow: Histologic study of the endometrium during the 27 hours after natural service. Amer. J. vet. Res., 1968, 29, 609-625.

Pettersson A: Cyclic variations in the intraluminal pressure in the isthmus of the oviduct in unrestrained gilts. J. Vet. Med. A 1991, 38, 337-343.

Rodriguez-Martinez H, Einarsson S: Influence of prostaglandins on the spontaneous motiltiy of the pig oviducts. Anim. Reprod. Sci. 1985, 8, 259 279.

Rodriguez H, Kunavongkrit A: Chronical venous catheterization for frequent blood sampling in unrestrained pigs. Acta vet. scand. 1983, 24, 318320.

Schams D, Baumann G, Leidl W: Oxytocin determination by radioimmunoassay in cattle. II. Effect of mating and stimulation of the genital tract in bulls, cows and heifers. Acta endoc. (Kbh.) 1982, 99, 218-223.

Viring $S$, Einarsson S, Nicander L, Larsson $K$ : Localization of the sperm "reservoir" at the uterotubal junction of the pig. Proc. 9th Int. Congr. Anim. Reprod. and A.I., Madrid, Spain. 1980, 5, 224227.

Zerobin K, Spörri H: Motility of the bovine and porcine uterus and fallopian tube. Advanc. vet. Sci. 1972, 16, 303-354.

\section{Sammanfattning \\ Effekten av stäreflexen, cervixstimulering och insemi- nering på intraluminella tryckvariationer $i$ istmusde- len av äggledaren hos gris.}

Fyra gyltor utrustades med 2 små tryckmätare placerade på 2 olika punkter inuti samma äggledares isthmus på morgonen dag $1 \mathrm{i}$ brunstcykeln. Mätningar av intraluminella tryckförändringar påbörjades samma eftermiddag. Det intraluminella trycket registrerades före, under och efter utlösning av ståreflexen, stimulering av cervix och insemination med antingen $100 \mathrm{ml}$ koksaltlösning eller helejakulat från en fertil galt. Tryckmätningar utfördes upp till 6,5 $\mathrm{t}$ efter inseminationen. Blodprov samlades var 30:e min samt efter varje manipulation med gyltorna. Blodproven analyserades på sitt innehåll av östradiol-17ß, östronsulfat, progesteron samt 15-ketodihydroprostaglandin $\mathrm{F}_{2 \alpha}$. Ingen av behandlingarna som gyltorna utsattes för resulterade i någon återkommande effekt på det intraluminella trycket $\mathrm{i}$ äggledarens isthmus. En ökning av 15-ketodihydroprostaglandin $\mathrm{F}_{2 \alpha}$ syntes dock cirka $4 \mathrm{t}$ efter insemination med helejakulat.

(Received November 12, 1992; accepted December 1, 1992).

Reprints may be requested from: Ann Pettersson, Department of Obstetrics and Gynaecology, Faculty of Veterinary Medicine, Swedish University of Agricultural Sciences, P.O. Box 7039, S-750 07 Uppsala, Sweden. 